\title{
Empirical Analysis on the Practical Feasibility of Timber Legality Verification Work in China
}

\author{
Jianquan Li, Shaozhi Chen \\ Research Institute of Forestry Policy and Information (RIFPI), Chinese Academy of Forestry (CAF), Beijing, China \\ Email: jqli2002@163.com
}

Received 18 January 2015; accepted 1 April 2015; published 2 April 2015

Copyright (C) 2015 by authors and Scientific Research Publishing Inc.

This work is licensed under the Creative Commons Attribution International License (CC BY). http://creativecommons.org/licenses/by/4.0/

(c) (i) Open Access

\section{Abstract}

With the acceleration of economic globalization and trade liberalization, illegal logging and timber trade, which are closely related to the ecological environment and climate change, have aroused extensive concern within the international community. Based on the authors' long-term experience and accumulated knowledge, as well as extensive field investigation, this article offers a range of observations. Firstly, it analyzes the worldwide significance and annual changes of China's forest products trade; secondly it reviews China's legal timber logging, transport and management systems and major challenges; thirdly, it compares timber legality verification schemes and methods around the world and summarizes experience of their implementation; fourthly, it proposes countermeasures and suggestions on strengthening the timber legality management in China; finally, the paper discusses the practical feasibility of timber legality verification work in China. The results of the authors' research show that strict forest logging quota management means the risk of illegally logging in China is relatively low, that legality verification in China can meet the international market demand for legal timbers and that launching timber legality verification work in China is therefore feasible. This would make a significant contribution to breaking through green trade barriers, enhancing China's position in negotiations, and promoting the standardization of the timber international trade.

\section{Keywords}

Legality Verification, Practical Feasibility, Source Tracking, Empirical Analysis, Countermeasure Suggestions

\section{Introduction}

The fact that legal timber trade can promote sustainable forest management has been widely recognized globally 
(Wiersum et al., 2013), and there has been a worldwide upsurge in action against illegal logging and trading. After 15 years of negotiations, the United Nations in 2007 agreed the Non-legally Binding Instrument on All types of Forests and this was followed by the UN Conference on Sustainable Development in Rio de Janeiro in June 2012, which nearly 130 heads of 193 member states and/or governments attended. Delegates engaged in indepth discussions regarding the institutional framework for a green economy geared towards the goals of sustainable development and poverty eradication. This culminated in them passing a final Conference declaration The Future We Want.

In the meantime there have been a range of international initiatives launched that are specifically aimed at countering illegal logging and illegal timber trade. The East Asian-Pacific Ministerial Conference on the Forest Law Enforcement and Governance (FLEG) was held in Indonesia in September 2001 and the EU initiated an action plan for the Forest Law Enforcement Governance and Trade (FLEGT) in May 2003. The first African FLEG Ministerial Conference was held in Cameroon in October 2003 and the Europe and North Asian FLEG Ministerial Conference was held in Russia in November 2005. Alongside the international FLEG processes (EFI, 2011) of Asia, Europe, Northeast Asia, etc.-all of which China attended-, a Sino-EU FLEG Conference was held in Beijing in September 2007, and the 1st Asia-Pacific Economic Cooperation (APEC) Ministerial Conference on Forestry was successfully held in Beijing in September 2011 (DIOC, 2012).

A range of developed countries have imposed legislative bans on illegal timbers entering their markets. In 2008, the United States amended the Lacey Act, expanding its coverage to the trade in plants, forest products, etc. Implementation of the amended act began in April 2010 (Brack, 2010). In 2010, the EU passed the Timber Regulation, which came into force in March 2013 (Chen \& Wu, 2013) and, in 2012, Australia ratified The Illegal Logging Prohibition Act, which was due to come into effect in November 2014 (Australian Government, 2013). Meanwhile, non-governmental organizations (NGOs) jointly initiated forest certification systems, with the aim of countering illegal logging through market mechanisms. Amongst others, the Forest Stewardship Council (FSC), Rainforest Alliance (RA), SGS, IKEA, have introduced Forest Management (FM) Certification, Chain of Custody (COC) certification of forest products, Verification of Legal Origin (VLO), Verification of Legal Compliance (VLC), etc. (Lawson \& MacFaul, 2010; TTF, 2010; Yang \& Yin, 2011).

Literature reviews show that in recent years, in tandem with its rapid economic development, China has become a major player in the production, trade and consumption of forest products from around the world and that China is playing a more and more important role in worldwide forest conservation and sustainable forestry development. At the same time, while China's governance system for timber harvesting and transportation is fairly comprehensive, it is also encountering a range of new challenges. For instance, while America and Europe are China's important partners in the international trade in forest products, the implementation of new regulations in these two regions has also had a profound effect on China's foreign trade in forest products. Therefore, in considering the feasibility of timber legality verification work in China, it is necessary to analyze China's legal logging, timber transportation, operations and timber management systems and the major challenges they face. It is also important to learn from international experience and to explore countermeasures and suggestions for ensuring legality of timber, improving market access for forest products and the safeguard rights and interests of China's forestry enterprises in the international arena.

\section{Methods and Materials}

\subsection{Methods}

\subsubsection{Literature Review}

By using online databases, such as cqvip, cnki, ScienceDirect, etc., and web-based platforms, such as Google, etc., the authors were able to identify and review relevant documents, to consult and categorize data related to Chinese's and global forest products trade, analyze standards for legal timbers, practical requirements, legality verification and tracking methods and to systematically summarize theories and practical experience. This provided a complete baseline understanding of the forward trends, key results and latest developments in this field, and a foundation for further studies and for field investigations.

\subsubsection{Questionnaire Survey}

Relevant leaders of local forestry departments, industry associations and forest industry groups sent a tailored questionnaire to the administrative staff and front-line workers of all forest enterprises, forest farms and/or re- 
lated business units via E-mail, and reminded them to send the questionnaires back after completion, or, to compile relevant presentation materials and to wait for the survey research group to take back such questionnaires, to collect relevant materials and to interview them. The questionnaire covers the basic status of each enterprise, management and operation condition, domestic policies implemented, foreign policies learned, the level of demand for business management and so on. These issues will be explored in more detail in Section 2.2.3.

\subsubsection{Field Research}

Based on those questionnaires and seminars, relevant researchers were dispatched group by group to the Greater Khingan Range, Heilongjiang, Fujian, Guangdong, Guangxi, Hebei, Beijing and some representative enterprises for field research and site inspection from July 2011 to May 2013. Here, they conducted face-to-face interviews on the status and problems of China's management of forest resources, the practical feasibility of identifying legal timber etc.

\subsubsection{Comparative Analysis}

China's forest products trade volumes were compared with those of the world as a whole and with those of Asia as a region, alongside a comparison of annual changes in the value of China's imports and exports. In addition, the study compared the standards for legal timber, as well as the verification methods and associated systems, and reviewed relevant achievements and experience abroad. The researchers also analyzed corresponding laws and practices. On this basis the authors offer their objective evaluation and conclusions.

\subsection{Materials and Sources}

\subsubsection{Data Sources}

The comparison between China trade in forest products and that of the rest of the world made use of relevant data published by FAO Forestry Trade Database. For changes in the national export and import of forest products the authors have utilized relevant customs statistics from the China Forestry Development Report which is compiled and published by State Forestry Administration (There are significant differences in the statistics offered by the two sources of trade data because of their different categorization of major forest products).

\subsubsection{Survey Location}

Guangzhou, Shunde, Zhongshan, Dongguan, Fengkai, Huizhou, Zijin and Shixing in Guangdong, Hailin, Suiyang, Dongning and Xinlin in Heilongjiang, Songling and Mohe in the Greater Khingan Range, Fenyi and Shanggao in Jiangxi, Shaxian, Nan'an, Ninghua and Xianyou in Fujian, Cangwu, Rongxian, Bobai, Beiliu, Luchuan and Wuzhou in Guangxi, Quzhou in Hebei, Miyun in Beijing, etc., as well as 3 - 5 representative enterprises of each of the above-mentioned, were investigated and surveyed.

\subsubsection{Investigation Content}

Relevant provisions surveyed include: the current logging, transport and management systems for timber, annual logging quotas, the procedures and basis for compiling timber production plans, application procedures for forest logging permits, acceptance, supervision and management systems for forest logging, application and monitoring procedures for timber transportation permits, and application and monitoring procedures for timber business permits. The authors also considered the current status and problems of the implementation of legal forest logging, transport and management, implementation of annual logging quotas and timber production plans, implementation of legal forest logging, transport and management permits and systems, evidence or reports on occurrences of illegally logging, etc.

The research also encompassed a review of the following: timber sources and purchasing practices of forestry enterprises, production and processing of timber products, commodity marketing and export, foreign policies, etc.; and, tracking and supply chain management systems of representative enterprises and their sources of timber, implementation and risks of illegality of timber, implementation and problems of labor and environmental protection laws, rules and/or conventions, etc.

Finally, the authors also considered opinions or comments on basic principles, criteria and indicators of legal timbers to be followed, opportunities and difficulties in developing verification and tracking of the legality of timber in China, and comments or suggestions on promoting the legality of timber in China. 


\subsubsection{Data Acquisition}

Among the electronic and paper questionnaires completed and collected from various regions, 166 questionnaires, containing 0.10 million words of statistical information, have been considered. The researchers also made visits to facilities and organized seminars, in which the participants included 92 companies and business units from 28 districts and/or counties of 7 provinces. These produced a further 0.30 words of notes, 117 copies of introductions, 31 copies of electronic materials amounting to of 0.13 million words, 2695 pictures with a total of $13 \mathrm{G}$, and 27 tape recordings of total session of 13 hours, 24 minutes and 31 seconds.

\section{Results and Analysis}

\subsection{Status and Changes of China's Forest Products International Trade}

Since the start of the $21^{\text {st }}$ Century, China's international trade in forest products has made great progress. China is the top exporter, globally, of major products such as wooden furniture, paper, wood-based panels and wood products.

\subsubsection{Annual Improvement in China's Global Position}

According to the FAO statistics database, the total value of global trade in main wooden forest products increased from US \$205.591 billion in 1991 to US \$493.526 billion in 2013, a 140\% increase. Meanwhile, the total value of China's trade in forest products increased from US $\$ 8.193$ billion to US $\$ 57.562$ billion-an increase of 6.03 times, which is 4.63 times higher than that of the rest of the world. China's share of the trade in main wooden forest products as a proportion of trade within Asia and that of the world (1991-2013) has undergone insignificant fluctuations between years. However, on the whole, they exhibited upward trends (Figure 1), and historical peaks; accounting for $11.66 \%$ of the total value of the world trade in 2013 and that $45.40 \%$ of Asian trade in 2011 (FAO, 2014).

\subsubsection{Continued Growth in Total Trade}

Although the value of China's import and export of forest products from 1992 to 2014 registered insignificant fluctuations between years (e.g. total value in 1993, 1996, 1998 and 2009 declined slightly) it still maintained an upward trend overall (Figure 2).

The volume of trade in forest products from 1992 to 2014 rose from US $\$ 9.188$ billion to US $\$ 139.948$ billion - a 14.23 times increase. At the same time, the value of exports rose from US $\$ 2.181$ billion to US $\$ 72.198$ billion - a 32.10 times increase and the value of imports rose from US $\$ 7.008$ billion to US $\$ 67.750$ billion—an 8.67 times increase (SFA, 2014). According to customs statistics, the trade value in 2014 was US $\$ 139.948$ billion, an increase of $8.9 \%$ on the previous year. The value of exports in 2014 was US $\$ 72.198$ billion-an increase of $12.0 \%$-and the value of imports was US $\$ 67.750$ billion, down by $5.7 \%$. The import volume of logs was 51.194 million $\mathrm{m}^{3}$, up by $13.4 \%$ and the volume of sawn timber imported was 25.746 million $\mathrm{m}^{3}$, up by $7.1 \%$.

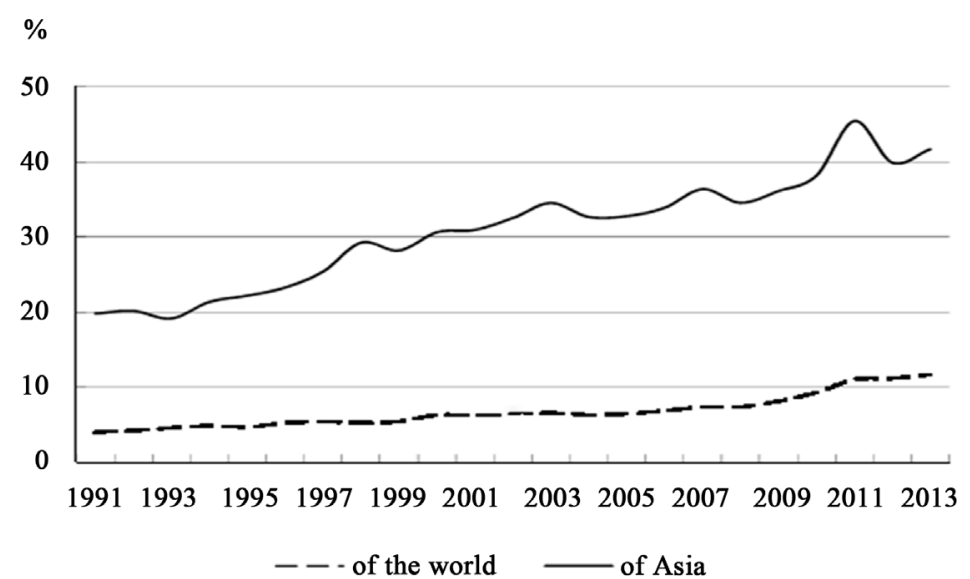

Figure 1. Chart showing China's share of international trade in wooden forest products relative to the rest of the world and to the Asia region from 1991 to 2013. 


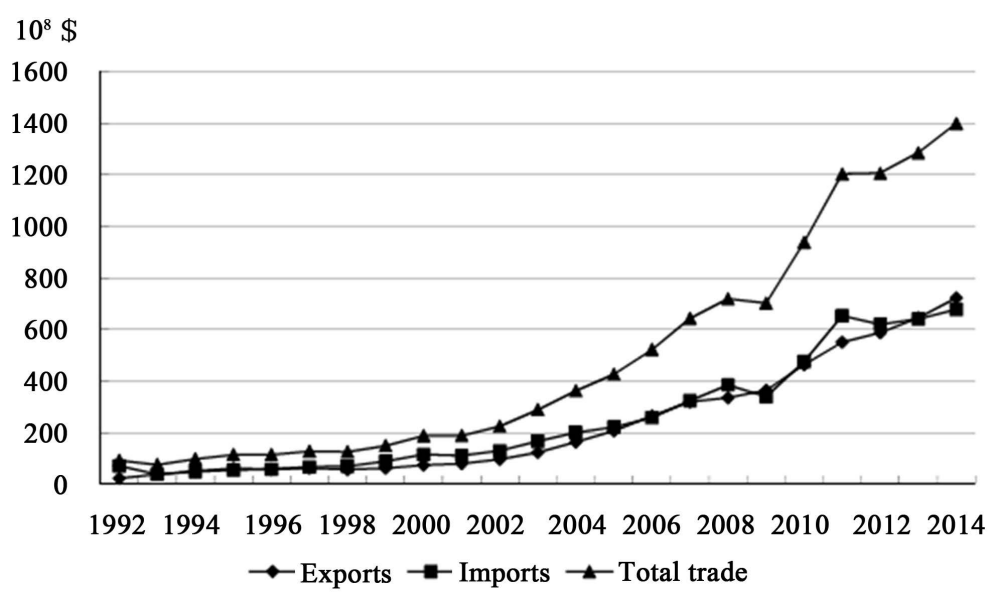

Figure 2. Trends in the value of China's import and export of forest products from 1992 to 2014.

\subsubsection{Import Trade in Continuous Ascension}

According to customs statistics, the total export value of forest products in 2010 accounted for US $\$ 47.51$ billion, an increase of $40.1 \%$ on the previous year. The value of imports in 2011 reached US $\$ 65.30$ billion-an increase of 37.6\%; however, the import value in 2012 fell slightly (Figure 2). In 2013 and 2014 import values reached US $\$ 64.09$ billion and US $\$ 67.75$ billion, equating to increases of 3.5\% and 5.7\% respectively.

\subsubsection{Export Trade Is Continually Increasing}

The value of China's exports of forest products started to show an upward trend in 2000, then declined sharply from 2008 till 2009 due to the effects of the financial crisis, and then increased significantly from 2010 to 2014 (Figure 2). The value of exports first exceeded that of imports in 2006, and has yielded an overall trade surplus of US $\$ 0.578$ billion over the past 10 years. The trade surplus in 2009 alone was US $\$ 2.414$ billion, while trade surpluses for 2013 and 2014 were US $\$ 0.367$ billion and US $\$ 4.448$ billion respectively. There were some trade deficits in the intervening years.

\subsection{China's Legal Timber Logging, Transport and Management Systems and Challenges}

\subsubsection{Institutional System}

China has rigorous supervision and management systems for forest logging, transportation, processing and sales, based on presentation of legal evidence, and has strict administrative enforcement of laws. At present, the country has a unified management system of licensing timber transport, although Guangdong, Fujian and some other provinces have also opened their own forestry administration systems, enabling them to allocate permits for forest logging and transportation online, and allowing the comprehensive management of timber logging, circulation, processing and utilization. The supervision and management systems have the following main components:

(1) Management System of Forest Logging.

1) Management of logging quotas is an important legal tool for protecting forest resources. As specifically stated in the Forestry Law of the People's Republic of China, forest logging quota and production controls should strictly adhere to the principle of consumption being lower than production, and must follow the management systems set out in annual logging quotas and timber production plans. State-owned forestry enterprises and/or institutions designate the annual logging quota for state-owned forests and trees, while county authorities set annual logging quotas for collectively or individually owned forests and trees. Relevant forestry authorities at the district/municipal/provincial level are in charge of ensuring balance in the system as a whole, and local government is responsible for reporting to the State Council every 5 years.

2) Timber Production Plan. This is a specific means by which the government can control and regulate the annual consumption of merchantable logs and to guarantee logging quotas are not exceeded. As provided in the Forest Law of the People's Republic of China, a unified timber production plan should be worked out by the government, and no annual timber production plan may exceed the approved logging quota. In the event of any 
logging exceeding the quota, this will incur punitive measures by the authorities. The government works out a unified annual timber production plan according to the approved annual logging quota, and strictly implements the management systems of quota acceptance, allocation and forest logging permits.

3) Forest Logging Permit. This is an important measure to ensure the implementation of logging quotas. As provided in the Forest Law of the People's Republic of China, any state-owned forestry enterprise or institution shall, prior to lumbering, apply for a bamboo or tree logging permit, and must strictly comply with the approved logging quota. As set out in relevant national policies, forestry authorities at all levels need to strengthen the audit of material sources of all timber processing and sales entities that are largely relying on consumable forest resources. It is prohibited to use any timber cut without a forest logging permit or other proof of it having been sourced legally.

4) Logging Acceptance and Supervision. National and local competent administrative authorities of forestry and township forestry stations are responsible for supervising the implementation of forest logging management systems. Forestry bureaus at the county level check the permit for the local logging, production and transport of timber or bamboo at random, and each forestry station inspects the timber transport documentation at a fixed site. Meanwhile forestry authorities and industry and commerce administration authorities streamline timber business units and processing enterprises in forest districts and key timber-producing counties as well as carrying out annual inspections, registrations and license renewals. They require the scope of business to proceed in line with relevant national laws, with regard to the state of the local resource and logging quotas or timber production accounting systems, and require that the number and the size of such units be reasonably determined. It is prohibited to individually resell or to smuggle. For its part, State Forestry Administration organizes inspections of the logging volume, freight volume and sales volume of each state-owned forest district every year, and supervises the forest logging.

(2) Supervision of administrative law enforcement of forestry. China's supervision system of administrative law enforcement of forestry effectively guarantees the implementation and supervision of legal logging.

1) A description of the administration law enforcement system is as follows. It has 5 levels of forestry administration, including the state, provincial, municipal (district), county and township-levels. The State Forestry Administration sets the forest logging quotas, which are implemented upon the approval of the State Council, and supervises the forest and bamboo logging and transport with permits. The provincial forestry departments set and implement their own local logging quotas, and supervise the forest and bamboo logging, transport and sales with a system of permits.

2) Systems and norms of administrative law enforcement. China has a sound law enforcement and supervision system, covering all aspects of the timber products business, such as logging, transport, processing, import and exports. It has established related systems of administrative law enforcement covering forestry, including the Procedural Provisions on Administrative Punishment of Forestry, the Measures for the Supervision of Administrative Law Enforcement of Forestry, the Administrative Punishment Hearing Rules of Forestry, etc. In case of any serious breach of any of such regulations, corresponding criminal violations shall be investigated.

3) Enhancement of law enforcement supervision agencies. The forestry security bureau is set up to guide the administrative law enforcement relating to forestry, and to urge to investigate and treat seriously cases in which forest resources and/or wildlife resources under special state protection are being destroyed. All levels of forest administration and public security organs are responsible for clamping down on illegal activities related to forests and each timber inspection post shall be responsible for checking relevant proofs of timber transport, and assisting the forest public security organs in handling major cases. The State Forestry Administration has also established offices of the commissioner for supervising timber resources in 13 provincial districts' forests, and these offices specifically supervise the utilization of local timber resources.

(3) Management of timber processing and sales. As set out in the Forestry Law of the People's Republic of China, timber processing and sales in forested districts shall be approved ahead of time by local forestry authorities above the county level. At present, most parts of China have implemented the licensing system for timber processing and sales. All entities and/or individuals engaging in timber processing and sales shall, prior to taking out their business licenses from relevant industrial and commercial administrations, obtain permits for timber processing and sales from relevant forestry authorities above the county level.

(4) Timber Transport Management System. It is important to ensure compliance with timber transport regulations, and to prevent any timber illegally cut from circulating. As required in the Forestry Law of the People's Republic of China, companies or individuals transporting timber from forested districts must be in possession of 
transport documentation issued by local forestry authorities. This timber transport documentation must be valid throughout the transport of the timber from the point of origin to the destination. It needs to be retained throughout the journey, and the description of the products in the permit must be consistent with the materials being transported. Local timber inspection posts reserve the right to stop any timber consignments that lack such documentation or are inconsistent with it. Forestry authorities above the county level may confiscate any illegally transported timbers, and impose a penalty on the owner, of up to $30 \%$ of the value of such timber.

\subsubsection{Major Challenges}

Although relevant laws and regulations of China have strict provisions on logging, and relatively complete management, supervision and enforcement systems of forestry have been set up, there are still some outstanding issues in practice:

(1) Lack of rules for the implementation of forest management. 1) Over-harvesting. In some places, because of economic interests, there are still cases of above-quota logging and/or logging without a license. There are only a very few competent authorities that do not conduct logging area survey design, that do not issue forest logging permits correctly or which do not carry out checks as required. Indeed, in recent years, statistics suggest that the licensed logging rate in logging areas and state-owned forest districts and the pass rate of forest logging permits have increased significantly (SFA, 2014). However, in some places, there are still cases of logging permit misuse; notably above-quota logging and logging without a permit.

2) Poor transport management. It is hard to supervise the transport of timber and timber products, because of the long distances and wide range of parties involved. a) Discrepancy between transport and logging permits: In some places, the transport of timber materials within the territory does not require any transport permit, thus creating the opportunity for criminals to acquire timbers in such places and convey them to the point of sale using transport permits issued elsewhere. This results in the legalization of unlawful felling or denudation. b) No checkpoints on expressways: The supervision of timber transport is poor, and there is a long-standing problem of some checkpoints levying fines rather than imposing statutory punishments in cases where timber is found to be transported without a permit.

3) Excessive processing and sales. In a few places, in the interests of developing the economy or because of the pressure to attract investment, local authorities neglect the bearing capacity of timber resources, and license batches of timber processing and sales enterprises without examination, thus causing an embarrassing situation of excessive harvesting and poor quality of wood products. The internal management of some processing plants is not standardized, giving rise to problems such as processing without permit, business activities that are beyond the scope of permits, lack of proper accounting, sales of semi-finished products or product made from timber that lacks the proper permits, etc.

(2) Industry associations not functioning properly. At present, most of the industry associations in China are basically affiliates of government agencies. They are characterized by excessive administrative functions, inadequate service functions and a lack of capacity to coordinate industrial development or bridge the gaps between all the enterprises involved. In particular, forest industry associations have poorly-developed organization and unclear division of responsibilities, and there is still much room for improvement in key areas, e.g. developing plans for guiding the growth of the industry, introducing self-discipline conventions to avoid vicious competition, standardizing enterprise behaviors, dealing with trade barriers, strengthening social responsibilities for forest management and maintenance, providing market information, reducing operating costs, etc.

(3) Weak support of modern information technology. The support and introduction of modern information technology in China's forest conservation need to be strengthened. A particularly acute need is for the construction of a management and support platform for legal timber supply through utilization of E-government, digitalization of forest district administration, information services, media technology, etc., innovating technical means and administrative services for timber logging, transport and management, and realizing the resource integration, collaborative interaction, efficient sharing and one-stop services.

(4) Deficiencies in the capacity building of enterprises. Nowadays, China's forestry enterprises have weak capabilities, and they still have great room for improvement in conceptual development, management innovation, competitive strategy, corporate culture, staff skills, branded services, foreign relations, etc. 1) Deficiencies in global planning and pioneering and innovative efforts; 2) poor management capabilities of modern enterprises; 3) lack of top-level design, without core competitiveness; 4) significant problems in institutions and mechanisms, and lack of employee loyalty; 5) shortage of well-known brands, and low value and poor quality of products; 6) 
lack of technical training, and inadequate follow-up services; and, 7) weak external communications strategies, and poor corporate image. In short, there is a big gap between the development strategies and the actual operating results.

(5) Lower levels of international exchanges and cooperation. Forestry is affected by international rules, and international exchanges and cooperation are of an important manifestation of a forest products industry's development. China faces a lack of comparative advantage in forest resources, a major discrepancy between supply and demand, little room for policy alternatives, low levels of internationalization, low level of exposure to international influences on the part of management personnel, lack of comprehensive international vision, limited efforts to recruit top talent, lack of international exchange in forest management, shortage of reputable foreign experts, narrow scope of cooperation, decentralized exchange cases, and lack of evaluation systems.

\subsection{International Experience in Timber Legality Verification Schemes and Methods}

At present, the international community has higher and higher requirements regarding the legality of timber and timber products. However, different countries, groups and/or individuals have quite different perceptions of what constitutes legality, and there is not yet a global consensus on this question. For example, the Japanese definition of legal is: logging activities comply with relevant laws and standard formalities of the timber-producing countries. By contrast an English definition is: logging enterprises have the legitimate rights to use forests, forest management organizations and all parties related comply with local and national laws, and all fees and taxes incurred have been fully paid. Then there is the definition in the EU Timber Regulation: timbers and timber products comply with the laws of the timber-producing countries ( $\mathrm{Li}$ et al., 2010). The author believes that legality is assured when the timber materials used by business units of forest products or lumber producers have been harvested and transported in compliance with all relevant local and national laws, forest management plans, land administration and forest exploitation regulations.

\subsubsection{Verification Standard}

When it comes to global timber legality verification schemes, there are five key criteria: a) the legal logging rights, which need to clearly define and describe the forest owner's legal status and authority by which timbers may be lawfully cut with complete adherence to regulatory requirements; b) the approved logging plan, by which logging enterprises observe all regulations and comply with all restrictions on timber production and logging; c) all taxes and fees are fully paid-logging enterprises to pay all taxes, fees and royalties incurred in a timely manner; d) the traceability of timber, requiring logging enterprises to document control and supervision of the supply chain for timber and timber products; and, e) comply with all related laws and/or conventions on labor, hygiene, environmental and social protections, and trade.

\subsubsection{Verification Methods}

There are five methods to identify the legality of timbers in the world: a) independent third-party certification, such as the FM and COC certificates issued by the FSC or PEFC (certification and accreditation programs), or the certificate of compliance issued by another independent certification body; b) government-led legality verification schemes, such as Indonesian Timber Legality Assurance System (TLAS) (van Heeswijk \& Turnhout, 2013), and the legality verification schemes of Ghana, Cameroon, etc. under the framework of the Voluntary Partnership Agreement with EU (VPA) (Ochieng et al., 2013; Ros-Tonen et al., 2013; Atyi et al., 2013; Wiersum \& Elands, 2013); c) regulations and/or rules promulgated by the industry associations, such as the risk evaluation and verification of timber sources organized by the European Timber Trade Association; d) large-scale enterprises' self-checking and related documents, such as IKEA’s IWAY Forestry Standard; and, e) equivalent documents provided by suppliers and verifying the legality of the origins of their timber materials, such as those required by French timber procurement policies (Wang et al., 2011). It is clear that, although international timber legality verification takes the forest certification as an important criteria, many countries in the world adopt flexible and effective coping strategies according to their national conditions, thus giving rise to the coexistence of forest certification documents, timber legality verification and equivalent documents.

\subsubsection{Key Experiences}

In order to reach all requirements related to the timber legality in the European and American markets, Chinese enterprises must provide evidence of legality, and achieve the traceability of timber sources. Using international 
experience for reference, the enterprises may also indicate the legality of timbers through the forest certification, or verify legality through passing any legality verification schemes overseen by a third party, industry associations or any government-led agency, or by voluntarily proving or verifying the legality of timber with presentation of a series of lawful documents. At present, forest certification costs are high, however, the coverage is narrow, the proportion of the certified forest products is small, and the practical application of certification is restricted (Deng, 2010; Liu, 2010; Carlsen et al., 2012). Therefore, it is hard to meet the development needs of the international market this way. Thus, the timber legality verification has comparative advantages over the forest certification, and it is now becoming the preferred way for the Chinese enterprises to achieve the legality and traceability of timber.

\subsection{Suggestions on Strengthening China's Management Countermeasures for Timber Legality Verification}

There are still many difficulties and problems in achieving all requirements related to the timber legality in the international market, which require strengthening of management and provision of support on aspects of rules and regulations, science and technology, verification schemes, enterprise competence and international cooperation.

\subsubsection{Improvement of Relevant Laws and Regulations}

China's three-permit management lays a solid foundation for ensuring the legality of timber, but it still needs to be further improved.

(1) Legitimate timber logging. a) Achieve the unified administration of all timber and/or standing timber (branch) logging activities on the unplanned forestation or non-forest land; b) Strengthen the issuance and acceptance checks for permits; and, c) clarify all detailed rules on imposition of punishments and regulations on above-quota logging and logging without a license.

(2) Timber Transport Management. a) Coordinate the issuance and acceptance of transport and logging permits, and adopt a unified format for timber transport documentation; b) indicate the application scope of timber transport documentation, correctly fill out the tree species, origin, quantity and flow direction of timber, and achieve the traceability of timber; and, c) set timber inspection posts on expressways, and strictly enforce relevant laws.

(3) Supervision of processing and sales. a) Strengthen the examination and approval management for timber processing and sales enterprises; and, b) supervise the formation, enforcement and punishment of internal rules and regulations of enterprises, and place emphasis on the inspection of processing and sales and account management.

\subsubsection{Strengthen the Support of Advanced Information Science and Technology}

(1) Establish comprehensive supervision systems for timber resources and also ecological monitoring, utilize 3S and positioning observation techniques to monitor the various types of timber resources and ecological conditions in a dynamic manner, generate timely feedback information on the resource, and adjust management and control behaviors accordingly; (2) develop electronic accreditation systems, ensuring authorized personnel from grass-roots forest management units directly apply and handle online data anytime and anywhere, put an end to black-box operations and administrative rents, save processing time, reduce travel costs, improve work efficiency, ensure forest administrations at the county, municipal and provincial levels have relevant authorities to verify, supervise and manage permits; and, (3) utilize E-government and web-based platforms to fully collect, analyze and publish forest resource management information, and attain timely updates and sharing of information at the national level.

\subsubsection{Establish the Timber Legality Verification Schemes}

China has already put forward a framework for timber legality verification schemes: (1) establish the government-led timber legality verification schemes. The application for timber transport documentation in China requires presentation of the timber logging license and other legal evidences. In principle, the timber transport documentation is enough to verify the legality of timber, however, with a view to perfecting the timber transport permit system, it is necessary to supplement it with information related to the raw material sources, tree species and legality of timber and finished products (such as timber logging license number); To be able to treat the 
timber transport documentation as the legality evidences of timbers and timber products would be not only economical but also practical; (2) Establish association-led third-party legality verification schemes. Establish timber legality assessment criteria and certification procedures and methods for determining the legality of timber sources in line with national conditions and the state of the forest and international requirements regarding the legality of timber. Establish timber legality management and permit issuing authorities to directly audit or entrust a third party to audit, and issue timber legality certificates; (3) Enterprises may voluntarily accept any thirdparty legality verification or conduct the field verification themselves.

\subsubsection{Strengthen the Capacity of Enterprises}

In line with to international market trends, Chinese enterprises should strengthen their capability, establish timber legality supervision systems, conduct third-party legality verification if necessary, actively cope with international trade barriers, meet relevant timber legality requirements, and improve their capabilities at the aspects of management innovation, competitive strategy, branded services, etc. (1) Global plan and innovation; (2) utilize modern enterprise management systems to improve service level; (3) complete top-level design to form the core competitiveness; (4) solve institutional problems, and improve staff cohesion; (5) strengthen brand building, and increase the quality and value of products; and, (6) strengthen skills trainings, and enhance follow-up service capabilities.

\subsubsection{Establish International Cooperation and Trust-Building Systems}

China is an important participant in global industrial supply chains, and also a key driver of the international trade in forest products. China will continue to strengthen global multilateral and bilateral cooperation and exchanges, will look to jointly conduct a series of pieces of research on legal timber trade practices, enhance its image as a major power of the international trade in forest products, improve its regulatory ability, and ensure the legality of raw timber sources for commercial forest products. (1) Strengthen the bilateral cooperation with major trading partners in the forest management and combat against illegal logging and trade, coordinate with customs in sharing data on the import and export of timbers and timber products, and exchange experience on forestry regulations and public procurement policies; (2) Establish the unified international timber legality verification system with major timber exporting countries such as Russia, Papua New Guinea, Gabon, etc., ensuring each batch of imported timbers has proof of the timber's legal sourcing back to the point of origin; (3) Share the research results regarding China's distinctive timber legality certification standards and systems with the international community, reach mutual recognition agreements on verification mechanisms with major trading partners and/or all countries, form a real multilateral cooperation and mutual trust system, and create a favorable environment for China’s timber product trade.

\subsection{Analysis on Practice Feasibility of Legality Verification Work in China}

Timber legality verification is a key to solving problems of illegal logging and associated illegal trade (Cashore \& Stone, 2012). Timber legality assessment and verification work requires active verification of the source of timber, strengthening of timber legality documentation, improving timber tracking systems and strengthening of supply chain management (Lin et al., 2011; Tysiachniouk, 2013). These approaches can provide the core basis for the research, proposal and criteria for timber legality verification, and improve credibility through the thirdparty verification.

\subsubsection{Difficulties in Providing All Documents Required}

China's forest logging permits are issued by competent forestry authorities at the county level. One aspect of handling the timber transport documentation is the requirement to submit the former forest logging permit to the forestry authority for archival purposes. While renewing the permit after processing, it is required that the applicant submit the former transport permit or evidence of legal timber trade. Thus, processing enterprises usually hold only timber transport permits. If necessary, timber logging licenses may be obtained from local forestry authority or relevant forestry enterprise, but this is subject to the scope of authority concerned, and it is difficult to do in practice. Moreover, timber transport documentation often varies between regions. In some provinces, finished product and semi-finished products, such as wood-based panels, etc. do not need any timber transport documentation. 


\subsubsection{Complete Key Documents}

Logging enterprises generally provide legal logging permits, specific instructions on logging restrictions, evidences of logging activities within the specified forest districts and appropriate levels of exploitation, timber procurement and tax payment receipts, certificates of compliance with CITES requirements and timber transport documentation. According to China's quota management systems, forest logging permits set out timber logging type, method, location, deadline, area, tree species, volume and output, as well as method, tree species, area and deadline after renewal; timber transport documentation provides evidence of legal timber transport; and, evidence that licensed business units have already held timber processing permits, and paid corresponding taxes and woods-raising funds while handling the timber logging permit. Thus, timber logging, transport and processing permits may prove the legality of domestic timbers; and, once recognized by the international community, such timbers will meet the relevant requirements of international market.

\subsubsection{Improve the Tracking System of Legal Timbers}

China's timber transport documentation specifies the supply unit, purchase unit, sources of timbers, origin, destination, tree species, product name, specifications, quantity, volume and valid term, providing the possibility of achieving traceability of sources of timbers. However, because of the varied approaches taken across different timber-producing areas, only the forest product origin area is stated in the documentation, thus causing difficulties in tracking the timber origin. Meanwhile, as a highly developed industry, the supply chains of all enterprises engaging in the processing of forest products are often very complicated. For example, one of the investigated enterprises manufacturing wood-based panels has its supply chain involving more than 80 primary processing enterprises and over 100 forest owners, so it is hard to achieve traceability of all timber materials. At present, most enterprises cannot effectively identify their timber sources yet, and they are in great need of establishing and improving the tracking systems for legal timber. Such systems typically include timber procurement programs, production, sales and supervision chain systems, timber origin supervision system, internal audit procedures and report feedback mechanisms, enabling the identification of legal and illegal timbers, collection of evidence of legality, to track timber sources and to identify forest product origins.

\subsubsection{Legal Timber Standards Provide a Basis}

The project team has already studied and proposed the criteria for legal timber, which can provide the core basis for China's legality verification schemes. Independent association/government-led third-party timber legality verification schemes may now be established according to the national conditions and the state of the forests. Meanwhile, studies on the legality verification procedures and management methods may be carried out, and timber legality supervision and permit issuing agencies may be established to audit or issue, or to entrust corresponding verification units to audit or issue, the legality documents.

\subsubsection{Improve Credibility through the Third-Party Verification}

China's forest management and supervision systems are perfect, and the timber logging, transport and processing permits issued may be used as the credible evidences of timber legality. However, some places still have problems of non-standard permit issuance, poor acceptance checks, incomplete evidences provided while the exported timber materials go through customs inspections, etc. Enterprises still face difficulties in completely collecting timber legality evidence, tracking the sources of timber materials, etc. From an international perspective, in addition to the well-developed timber legality tracking system, enterprises also need to improve their credibility through independent third-party legality verification or their own field tests.

\section{Discussion and Conclusions}

\subsection{Discussion}

Although it is feasible to carry out the timber legality verification work in China, there are still some problems and difficulties in meeting all legality-related requirements of the international market for forest products. Therefore, China needs to further understand trends in the development of the world timber legality verification schemes and methods, deepen international exchanges and cooperation, learn from relevant international experience and findings as appropriate, continue to strengthen timber legality permit management, improve timber tracking systems, clarify the necessity and urgency of carrying out the practical research on the criteria for legal timber, and prove the significance and practical feasibility of supporting China's timber legality verification 
work with advanced science and technology. Also, it is necessary to take advantage of modern means and advanced information technology, to achieve multilateral communication and collaboration, and to efficiently manage all chains of legal timber logging, processing, transport, sales and consumption, timely collection and sharing of information related to research criteria, international trade policies and regulations, categories and quantities of cross-border forest products, cargo certificates issued by customs, etc., and to promote the process of China's timber legality verification.

The project research has gained abundant firsthand material, and has placed particular emphasis on qualitative analysis of the Practical Feasibility of Timber Legality Verification Work in China. It would be advantageous to strengthen the quantitative analysis in this article; of course, and another paper with more detailed quantitative analysis derived from questionnaire responses will be published later. At the same time, the main reason for the significant differences of China's forest products trade value between FAO's data and Chinese customs' data is the different statistical calibration systems. Whereas Chinese customs' data included all wooden forest products and non-wood forest products, the FAO's data only includes main wooden forest products and does not include the wood furniture and wood floor and other wooden forest products which have been China's main wood products exports. A further point is that this paper has focused on the domestic timber supply. Research on legitimate management of imported timber will be further discussed to lay the work foundation of timber legality verification more fully in China; and research on China's net imports of wood will also be carried out, in order to address misunderstandings and eliminate the international community's criticism of China's timber import practices.

\subsection{Conclusion}

(1) China's forest logging quota management is strict, and there is little risk of illegal logging. It is still hard for China's forest products to reach relevant legality requirements in the international market, however. In some places, there are still some bad phenomena occurring but national legal forest logging, transport, processing and management systems are strictly enforced and supervised, and are having quite good results, so, on the whole, the proportion of timbers illegally cut or from unknown sources is relatively low.

(2) Legality verification can meet all demands for legal timbers in the international market. In addition to use of forest certification, Chinese enterprises may also reach the timber legality requirements in the American and European markets through third-party/association/government-lead legality verification, or through providing a series of legitimate documents, or through voluntarily proving or verifying the timber legality and achieving the traceability of the source of the timber.

(3) The work to developing timber legality verification in China is entirely feasible. China's gross trade value of forest products has continuously increased with the Chinese industry's international status improving year by year. The system of timber logging and transportation with permits and the processing and sales of timber products with permits constitutes a unified supervision and management system for forest logging and timber circulation. In addition, China has already carried out practical research on forest certification (Shen et al., 2010; Wang, 2013), legal timber criteria and timber legality verification. China has also established its own timber legality verification schemes, has conducted extensive international exchanges, and has rich experiences in scientific research and practice. Therefore, to carry out the timber legality verification in China is feasible.

\section{Acknowledgements}

Acknowledgments to the funds for the Research on China's Timber Legality Verification Standard System Breaking through the International Trade Barriers, as one of the Major Cooperation Projects of the National Soft Science Research Programme (2012GXS2B009) and the matching funds support for the Forestry Soft Science Research Project of State Forestry Administration (2013-R02). Acknowledgments to project group researchers, such as Minli Wan, Bin Xu, Rong Zhao, Yong Chen, Haiying Su, Faquan Gao, Fuhua Zhou, Kang Tian \& Jie Chen et al., their field investigations and abundant firsthand data. Acknowledgments to Mr. Mike Davis from the Global Witness, he was hard work for the careful revision of language in this paper as an expert.

\section{References}

Atyi, R. E., Assembe-Mvondo, S., Lescuyer, G., \& Cerutti, P. (2013). Impacts of International Timber Procurement Policies on Central Africa's Forestry Sector: The Case of Cameroon. Forest Policy and Economics, 32, 40-48.

http://dx.doi.org/10.1016/j.forpol.2012.12.006 
Australian Government (2013). The Illegal Logging Prohibition Act 2012 received Royal Assent on 28 November 2012 and is now law in Australia [EB/OL]. http://www.daff.gov.au/forestry/international/illegal-logging

Brack, D. (2010). Controlling Illegal Logging: Consumer-Country Measures. London: Chatham House.

Carlsen, K., Hansen, C. P., \& Lund, J. F. (2012). Factors Affecting Certification Uptake-Perspectives from the Timber Industry in Ghana. Forest Policy and Economics, 25, 83-92.

Cashore, B., \& Stone, M. W. (2012). Can Legality Verification Rescue Global Forest Governance? Analyzing the Potential of Public and Private Policy Intersection to Ameliorate Forest Challenges in Southeast Asia. Forest Policy and Economics, $18,13-22$.

Chen, X. Q., \& Wu, S. F. (2013). Impacts of the Amendments to the U.S. Lacey Act on the Export of China's Timber Products. Forestry Economics, 1, 62-66. (In Chinese)

Deng, Z. G. (2010). China Forest Certification Research Summary. Problems of Forestry Economics, 30, 458-461. (In Chinese)

Department of International Organizations and Conferences (DIOC), SFA (2012-11-23) Ten Years of Forestry: Overview of International Exchanges \& Cooperation [EB/OL] [2013-5-19]. (In Chinese) http://www.forestry.gov.cn/portal/main/s/72/content-572335.html

EFI (European Forest Institute) (2011). Support Study for Development of the Non-Legislative Acts Provided for in the Regulation of the European Parliament and of the Council Laying Down the Obligations of Operators Who Place Timber and Timber Products on the Market.

FAO. Forest Products Trade Database [EB/OL] (2014-07-31) [2015-01-30]. http://faostat.fao.org/site/626/default.aspx\#ancor Lawson, S., \& MacFaul, L. (2010). Illegal Logging and Related Trade, Indicators of the Global Response. London: Chatham House.

Li, X. Y., Chen, X. Q., Hou, F. M. et al. (2010). Analysis on the Connotation and Reference Point of the Green Government Procurement of Forest Products. Resource Development \& Market, 6, 539-543. (In Chinese)

Lin, Y. H., Lin, S., \& Qiu, R. Z. (2011). RFID-Based Tracking System Design of Raw Materials of Forest Products. Forest Engineering, 4, 34-37. (In Chinese)

Liu, H. C. (2010). Present Situation and Recommendations on the FSC Certification of Forest Products. Knowledge Economy, 18, 40. (In Chinese)

Ochieng, R. M., Visseren-Hamakers, I. J., \& Nketiah, K. S. (2013). Interaction between the FLEGT-VPA and REDD+ in Ghana: Recommendations for Interaction Management. Forest Policy and Economics, 32, 32-39. http://dx.doi.org/10.1016/j.forpol.2012.07.003

Ros-Tonen, M. A. F., Insaidoo, T. F. G., \& Acheampong, E. (2013). Promising Start, Bleak Outlook: The Role of Ghana’s Modified Taungya System as a Social Safeguard in Timber Legality Processes. Forest Policy and Economics, 32, 57-67. http://dx.doi.org/10.1016/j.forpol.2012.11.011

SFA (State Forestry Administration) (2014). China Forestry Development Report 2014. Beijing: China Forestry Publishing House.

Shen, L., Zeng, X., \& Xie, D. M. (2010). Present Situation of the World Forest Certification and Its Implications in China’s Forest Certification. Jiangxi Forestry Science \& Technology, 1, 32-36. (In Chinese)

TTF (Timber Trade Federation) (2010). Background to the RPP (Responsible Purchasing Policy). London: Timber Trade Federation Responsible Purchasing Policy Document.

Tysiachniouk, M. (2013). Fostering Transparency in the Transnational Supply Chain: From Russian Forest Producers to Consumers in Europe and the USA. Forest Policy and Economics, 31, 3-11. http://dx.doi.org/10.1016/j.forpol.2012.02.011

van Heeswijk, L., \& Turnhout, E. (2013). The Discursive Structure of FLEGT (Forest Law Enforcement, Governance and Trade): The Negotiation and Interpretation of Legality in the EU and Indonesia. Forest Policy and Economics, 32, 6-13.

Wang, J. X. (2013). China's Standard Framework of Forest Certification. China Quality Certification, 1, 39-40. (In Chinese)

Wang, X. Z., Su, H. Y., He, Y. Y. et al. (2011). Impact Assessment and Reference of the Green Procurement Policies on Forest Products in Major Developed Countries. Forestry Economics, 11, 87-91. (In Chinese)

Wiersum, K. F., \& Elands, B. H. M. (2013). Opinions on Legality Principles Considered in the FLEGT/VPA Policy in Ghana and Indonesia. Forest Policy and Economics, 32, 14-22.

Wiersum, K. F., Lescuyer, G., Nketiah, K. S., \& Wit, M. (2013). International Forest Governance Regimes: Reconciling Concerns on Timber Legality and Forest-Based Livelihoods. Forest Policy and Economics, 32, 1-5.

Yang, L. H., \& Yin, S. H. (2011). Study on the Difficulties and Countermeasures for China's Trade of Forest Products under New Situation. Problems of Forestry Economics, 31, 294-297. (In Chinese) 